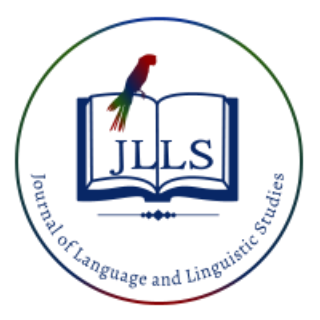

Available online at www.jlls.org

JOURNAL OF LANGUAGE AND LINGUISTIC STUDIES

ISSN: 1305-578X

Journal of Language and Linguistic Studies, 17(1), 431-444; 2021

\title{
Analyzing Jhumpa Lahiri's narrative The Namesake: A breakthrough beyond
}

\author{
text
}

\author{
Mohammed Ilyas a ${ }^{\text {iD }}$, Naeem Afzal ${ }^{\text {b }}$ iD \\ ${ }^{a}$ Prince Sattam bin Abdulaziz University, Al-Kharj, Saudi Arabia \\ ${ }^{b}$ Prince Sattam bin Abdulaziz University, Al-Kharj, Saudi Arabia
}

\section{APA Citation:}

Ilyas, M., \& Afzal, N. (2021). Analyzing Jhumpa Lahiri's narrative The Namesake: A breakthrough beyond the text. Journal of Language and Linguistic Studies, 17(1), 431-444. Doi: 10.52462/jlls.27

Submission Date: 04/01/2021

Acceptance Date: 15/03/2021

\begin{abstract}
Diasporic literature surfaced in the post-colonial era and contributed much to the literary and educational ethos with genres and sub-genres like expatriate writings, immigrant writings, multiculturalism, hybrid writings, and others. This study analyses Jhumpa Lahiri's The Namesake - as a fictional tale of a hybrid immigrant family that traverses between acculturation and deculturation. The novel is about cultural identities, both real and hyphenated, and about characters and events that oscillate between two extremely opposite cultures. Many diasporic themes emerge such as alienation, marginalization, rootlessness, distant homeland, and expatriate sensibility. The thematic content analysis approach was used to investigate the text by adopting Fairclough's (1989) three-dimension framework of critical discourse analysis (CDA): textual analysis (description), process analysis (interpretation), and social analysis (explanation). This study finds evidence that The Namesake is a perfect specimen of a narrative text that exposes the (diasporic) ideology hidden in its hybridity, hinting at the inter-mingling of two ideologies within a single text. It gives evidence of Fairclough's 'intertextuality' or 'multifunctionality of a text. The findings thus prove that the novel represents the ideology of diaspora from an immigrant's point of view. Towards its contribution to the educational domain, this study recommends that diasporic narratives such as The Namesake can be used to teach CDA techniques for exploring hidden ideologies embedded in a literary text.
\end{abstract}

Keywords: diasporic narrative; The Namesake; immigrants; CDA; ideologies; language

\section{Introduction}

Jhumpa Lahiri's The Namesake (2004) is a diasporic discourse about an Indian family who migrated to the United States, only to find themselves amidst strangers, displaced geographically and culturally. In this story of two generations, Ashoke and Ashima are the first-generation immigrants, and their children Gogol and Sonia, the second-generation immigrants. Though Lahiri delves much on names to stand as the distinction between East and West, there are also larger issues of marginalization, homelessness, haunting about the past, failure to assimilate with a new culture, and

\footnotetext{
${ }^{1}$ Corresponding author.

E-mail address: m.ebrahim@psau.edu.sa
} 
failure to cope up with a new cultural identity. The second generation of immigrants, despite having been born in America, felt more discrimination, mostly due to their parents' names, their accent, and ancestral heritage. Gogol, for instance, encountered this discrimination at a departmental store when the salesperson laughed at his parents' accent.

There are various juxtapositions in the novel set in the late 1960s up to the year 2000 - the contrast of the past with the present, comparing the Indian Bengali region with parts of Cambridge, Boston, and even neighborhoods in New York; comparing the rich India cuisine with the American fast food; contrasting the Indian customs and rituals, particularly in the event of a marriage or a death in the family with those in America. The protagonist, Gogol ake Nikhil strives between his two names, symbolizing two geographical, racial, and cultural identities. When he is dating Maxine, a young American woman, Gogol feels a sense of belonging, "of the city," but when he meets his childhood friend, Moushumi, whom he later marries, he thinks about his past, goes nostalgic, remembers, and forgets, and is burdened with a sense of loss. Gogol's parents, Ashima and Ashoke, are living a "transplanted" life of immigrants in their adoptive home, America. Ashima, often reminiscences about her Indian home, reads old letters from her parents, pays homage to the departed relatives according to the Indian customs.

Owing to these juxtapositions, nostalgic visitations, and a novel in the garb of a diasporic narrative, a critical discourse analysis of Lahiri's The Namesake required a much broader approach. Instead of carrying out a linguistic or lexical analysis of the text of the novel, this study attempted to establish a connection between two genres: expatriate writings or diaspora and critical discourse analysis. The study also premised that the relationship of expatriate or diasporic writing with CDA is complementary. On one level if the novel is a fictional narrative carrying expatriate or diasporic features; on the other level, it is also a social discourse, a narrative of cultural displacement, ideally suitable for conducting a critical discourse analysis.

For the purpose of CDA, the study adopted Fairclough's three-dimensional frameworks as the analytical tool to examine the generic relationship between expatriate ideologies and CDA. Fairclough's (1989, 1992a, 1992b, 1995; 2000, 2001b) prescribed three inter-related processes of analysis of a literary or a textual discourse namely text analysis (description), process analysis (interpretation), and social analysis (explanation). These three dimensions can be applied to investigate a diasporic or expatriate novel or any immigrant writing by segregating their verbal or visual images in the text (description of objects); by identifying the processes by which the images of those objects were expressed (interpretation) and by understanding the socio-historical conditions behind these processes (explanation). CDA's approach has been found critical to investigate social problems and generate results that relating to social, political, and cultural context (Sameen, Farid, \& Hussain, 2021).

\section{Problem statement}

The Namesake is not just a novel but a human experience in a world where the family has fewer opportunities of building a cultural identity or nurture familial obligations on foreign soil. This is a story of Ashoke and Ashima who broke their family customs back home in India and migrated to America, only to encounter the annihilation of their human self and loss of family bonding in the name of geographical, linguistic, and cultural differences. They are reduced to marginalized individuals in their attempt of acculturation and inter-mingling with the American society.

The application of Fairclough's three-dimensional approach in a diasporic novel of this nature is particularly useful to focus on three things: to identify text signifiers or such specific linguistic selections that contribute to understanding the text; to interpret any juxtapositions and sequencing of 
events and to place the text in a socio-historical and socio-cultural context. Fairclough (2000, 2001a) emphasizes that texts are actually "socially regulated" discourses and therefore they undergo a process of a carefully selected textual production; use discursive practices to understand the text and finally conduct an explanation of social and cultural events. A major advantage of making use of Fairclough's approach to CDA is that it allows multiple entry points of analysis, that is, one can begin the analysis of the text from any dimension. What matters is that the end result must be mutually explanatory. Due to this advantage, the researcher-analyst can establish interconnections and identify discourse patterns to describe, interpret and explain the text.

Moreover, in expatriate or Diasporic writings, when a critical discourse model is adopted, it is much easier to identify the ideological structures in the text, so evident in the racial discourses of cultural plurality and diversity, discrimination, and oppression. The CDA provides an opportunity for the researcher to understand clearly the underlying meanings of the narrative discourse, and concurrently illustrate the dialectic relationship between the text and society (Alba-Juez, 2009; Brown, \& Yule, 1984; Gee. 2010; Schiffrin, Tannen \& Hamilton, 2001). However, there is also a major disadvantage. The CDA model has so far been used in media discourses or political speeches, social power abuse or works dealing with power and politics as the model ideally suits studies written about dominance and inequality in social and political contexts (van Dijk, 1990, 1997, 1998a, 1998b) or about 'hidden ideologies' and narrative theories in the texts (Evans-Agnew, Johnson, \& Boutain, 2016; O'Neill, 1996). But when it comes to a text as a fiction, particularly in the Diasporic genre, the researcher must distinguish Text from Discourse since 'Text' only provides the structure of the embedded message while "Discourse" provides the discursive and social process embedded in the text (Heller, 2001; O’Neill, 1996). This is similar to van Dijk's (1998) Socio-Cognitive model which emphasizes more on scrutinizing the text, decomposing it, and identifying the hidden ideologies and meanings. This paper made use of Fairclough's three-dimensional model in the light of these recommendations and prepared a theoretical model (Figure 1) showing the relationship between the CDA approach and the expatriate or diasporic texts.

\section{Literature Review}

Wodak \& Meyer (2009) expostulate three forms of social representations in any kind of discourse: Knowledge about people or groups and their cultural sensitivity; Attitude of people toward social and cultural norms; and Ideologies that govern their Social Discourses. The amalgamation of these three elements helps readers understand societal structures. Stubbs (1997) though focuses on lexical and grammatical patterns but also talks about language and culture and registers a relationship between texts and social institutions. Fairclough (2001b) considers discourse as interdisciplinary; van Lauwen (1996) supports Fairclough by adding that there could be two kinds of relationship between discourse and social practices; discourse itself (as) social practice, and discourse as a form of action, as what people do for or with each other. Last, but not least, there is a discourse in the Foucaultian sense, where discourse represents social practice(s) as forms of knowledge (1993).

Talking about performing critical discourse analysis of narrative texts (O'Neill, 1996), van Dijk (1983) had recommended a sociolinguist approach to analyze a story or a novel. The rationale is that a story or any fictional narrative not only uses different structural categories according to the cultures but also puts constraints on the narrator, audience, events, and social customs and rituals (van Dijk 1983). Hatch and Lazaraton (1991) suggest six elements to do a critical discourse analysis of a story: Setting in time and place, the objective of the story, problem statement, characters, resolution, and conclusion. 
Several past studies have used Fairclough's and van Dijk's CDA approaches to investigate literary genres from different perspectives (Awan \& Yahya, 2016; Awan \& Raza, 2016; Abdu \& Khafaga, 2019; Amir and Mehmood, 2018; Mahmood \& Majeed, 2019). Hua (2013) used the conceptual framework of Critical Discourse Analysis for her analysis. She examined the common-sense assumptions about gender, prevailing in British society that underlies the use of language in Jane Austen's novel Sense \& Sensibility. Bilal (2012) makes use of van Dijk's Socio-Cognitive model to elaborate relationships between language and ideology to analyze 'The Gift of Magi'. Awan and Yahya (2016) conducted a critical discourse analysis of Ahmad Ali's Novel Twilight in Delhi. Awan and Perveen (2015) analyzed the poems of Sylvia Plath to discussed feminism in Plath's poetry. Kiren and Awan (2017) analyzed Jane Austen's Pride and Prejudice to study the cultural diversity in the novel; Ilyas (2020) attempted a CDA of Ellison's The Invisible Man to relate the genre of Afro American Fiction or fiction written in the tradition of slave narratives. The discourse analysis of Achebe's Things Fall Apart (Paziraie, 2012) is a similar attempt to relate CDA with the translation genre in the postcolonial era.

Likewise, Sabir and Kanwal (2018) used Fairclough's three-dimensional model to investigate the poetry genre and selected Robert Frost's poem Fire and Ice. The study focused on the interconnections and patterns of the text and analyzed the hidden agenda of the highly didactic poem. Bezar, Azhar, and Akhter (2018) investigated William Blake's poem Ah! Sun-flower explores the relation of the poem with social structures of authority and unequal power relations of the poet's contemporary society by using Fairclough's three-dimensional model. Ahmad and Ibrahim (2018) investigated yet another genre of popular fiction and selected Harry Potter and the Sorcerer's Stone by the British Novelist J. K. Rowling using Fairclough's model of CDA. Through social analysis (representation of women, beauty myth, sexuality, physical oppression, social oppression, self-identity, public-identity), the study claimed that Harry Potter is a social gender-biased novel that portrays a dominant male society.

In the journalistic and nonfiction genre, Hosseini and Sattari (2018) investigated the linguistic, ideological, and social aspects of Naguib Mahfouz's The Beggar at the levels of description, interpretation, and explanation in the light of Fairclough's CDA. The purpose was to understand the sociological elements along with their interpretations; and appreciate the effect of sociological context on a text and processes, which allow the creation of such a text. Focusing on the political treatises, Khan and Qureshi (2018) critically analyzed the role and politics of voice in Khaled Hosseini's The Kite Runner and A Thousand Splendid Suns in terms of categorical and stereotypical representation of the Pashtuns. Based on Fairclough's model of CDA, the study revealed the use of linguistics/textual forms such as lexicalization, patterns of transitivity, activization and passivization, choice of mood, information focus, and use of cohesive devices.

This review of the literature indicates that relatively less attention has been paid to diasporic literature. Hence, this research study rightly applied Fairclough's model to study The Namesake (2003), a diasporic novel by Jhumpa Lahiri.

\section{Theoretical Framework}

Fairclough $(1989,1992 a, 1995,2001$ a) described that a text is not a process rather than is a product and is just a part of discourse - the whole process of social interaction. He developed a threedimensional framework of CDA consisting of three stages: description, interpretation, and explanation. The first stage, description, "is concerned with formal properties of the text" (p. 26) where the text is the object of analysis, which generally deals with identifying and labeling certain formal properties or features of the language such as, vocabulary, grammar, and textual structures. The second stage, 
interpretation, "is concerned with the relationship between text and interaction" (p. 26). In this stage, the text is seen "as the product of a process of production and as a resource in the process of interpretation" and analysis deals with "cognitive processes of participants" (pp. 26-27). The third stage, explanation, "is concerned with the relationship between interaction and social context - with the social determination of the processes of production and interpretation, and their social effects" (p. 26).

The analysis in this stage deals with social events and social structures that shape and are reshaped by events. Figure 1 presents the inter-textual analysis (Fairclough, 2003), using inter-discursive patterns or 'hybrid' texts spread across the three dimensions of Fairclough's theory. Fairclough would call it 'recontextualization' of texts or discourses (2003, p. 30), i.e., shifting from one context to another or 'multi-functionality' of the text.

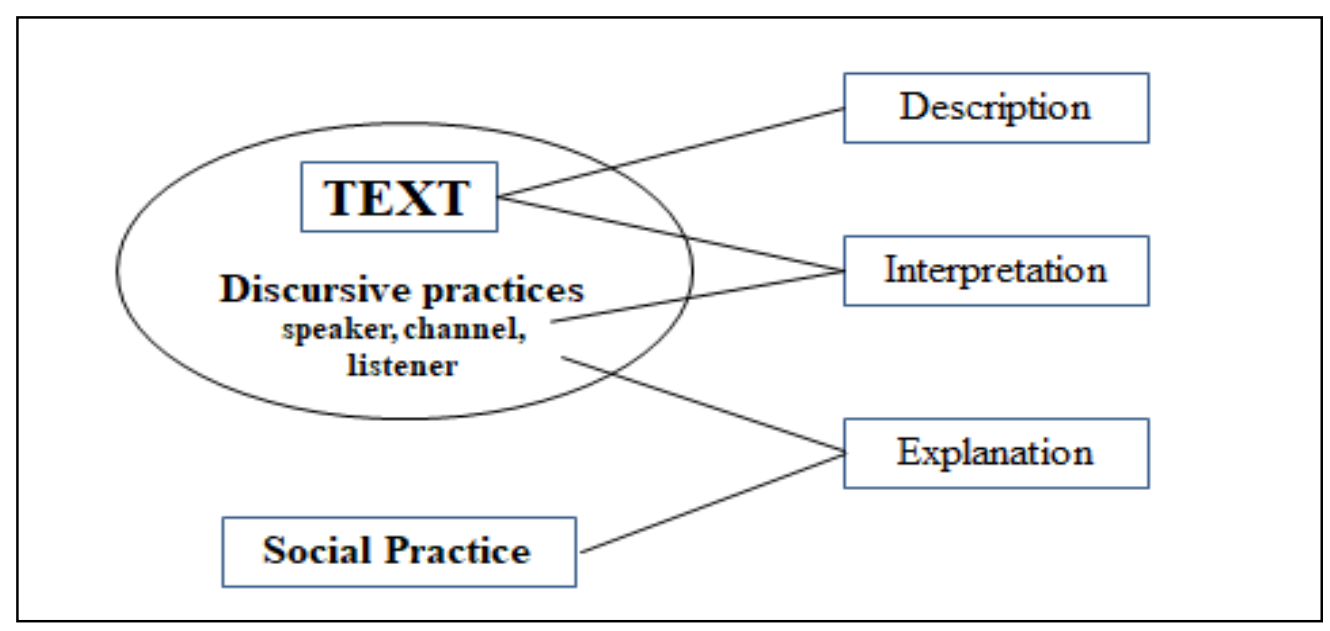

Figure 1. A theoretical model based on Fairclough's Three Dimensional Theory

\section{Research Methodology}

CDA does not comprise a "how-to-do" or "a ready-made" approach to any social analysis. However, it emphasizes in-depth theoretical of social problem Janks (1997). This requires selecting certain discourses and discourse structures to analyze and adopt methods of research in the analysis (van Dijk, 2001). This study applies Fairclough's (1989) model for CDA widely used to investigate different literary works (e.g. see Ahmad \& Ibrahim, 2018; Bezar, Azhar \& Akhter, 2018; Hosseini \& Sattari, 2018; Khan \& Qureshi, 2018; Mahmood \& Majeed, 2019; Sabir \& Kanwal, 2018). CDA's framework has been found useful for qualitative studies (Ziad \& Ouahmiche, 2019). The qualitative data in the form of language and discourse were examined in Jhumpa Lahiri's diasporic novel The Namesake (2003). The content analysis technique was used for close reading and understanding and interpretation of the text. This approach was found useful for revealing hidden meaning and making sense of characters' experiences and other phenomena depicted in novels by Jhumpa Lahiri (Istari, 2018).

This study applied Fairclough's (1989) three-dimensional model for this study. In the first step of analysis, description, the text was examined on characters' use of language, their behavior, and anxieties related to their identities, which describe a contravention of the real identity of characters. Fairclough called it 'recontextualization' of texts or discourses (2003, p, 30), i.e., shifting from one context to another offering readers an understanding of the 'multi-functionality' of the text.

In the second step of the process analysis or interpretation stage, this study examined Fairclough's suggestion of emphasizing situational context and attempted to find answers to question like 'What, 
Who and Why' about situations in the novel. The language was thus seen only as a vehicle to interpret the process of producing a text. In the third step of the social analysis or explanation stage, the focus was on the use of language in a social context (Fairclough, 1992) or in "areas of social practices" (Foucault, 1989; p 25). Both Fairclough and Foucault differentiated between discourse and language. Hence, this study looked at language only as a manifestation of a discourse, or about social events and practices.

\section{Discussion and analysis}

\subsection{Textual analysis (description)}

Both Fairclough (2003) and van Dijk $(1983,1997)$ consider textual analysis linked to linguistics including phonetic and phonological analysis of sounds; grammatical analysis of words, phrases, and sentences; semantic analysis of word meanings both metaphorically and cognitively; and pragmatic analysis in specific socio-political contexts. The text of current research has evidence that can aid in such textual analysis. The text for the current study is titled The Namesake which is suggestive of a description about identities, which are mixed and imposed ones, contravening with the real identity of the characters. Gogol is confused about his name, which is not Indian like, he feels it is not his own and therefore he legally changed it to Nikhil. He feels that by changing his name from Gogol (a foreign identity) to Nikhil (Indian identity), he has become a different person. Though many BengaliAmerican families, who live in the US for several generations, have adopted American nick-names for their children and spouses but they are still sticking to Indian names and their cultural tradition, to preserve the sanctity and meaning of the names. This is revealed when Ashoke died, and the wife showed her respect and intimacy with her husband's name by using pronouns such as 'he' and 'him' rather than taking his first name.

This is a good example of inter-textual analysis (Fairclough, 2003), using inter-discursive patterns mixed together within the same text. Figure 2 contextualizes this phenomenon.

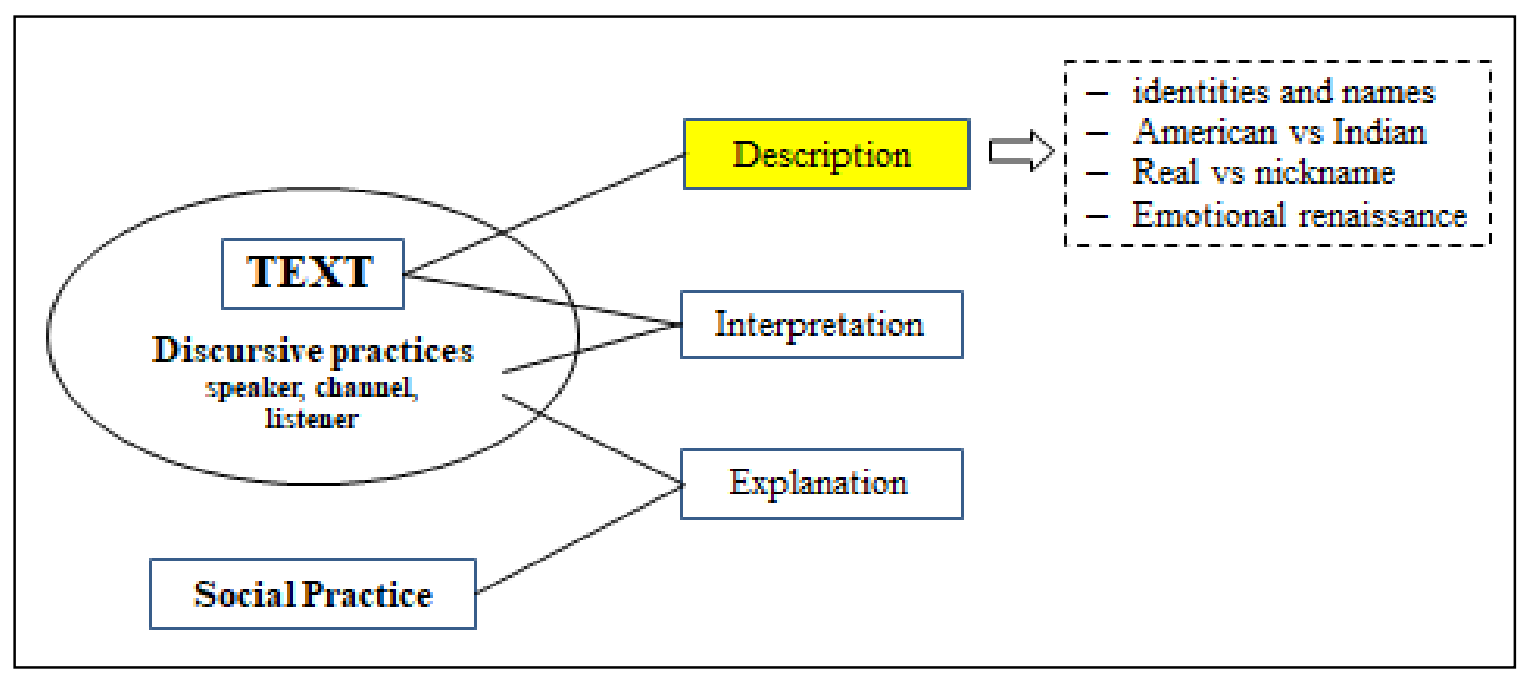

Figure 2. Fairclough's textual analysis (description)

It is not only difficult for Gogol to continue with a foreign identity but he also dislikes carrying the last name 'Ganguly' which was a symbol of Indian descent, of belonging to a "second-generation," being the child born in America of Indian parents. Moreover, using the last name 'Ganguly' reminded him of the English colonial regime in India. He, therefore, fluctuates between his two identities, which 
Fairclough would call 'recontextualization' of texts or discourses (2003, p. 30), i.e., shifting from one context to another. The names of two women characters, Sonia and Moushumi, also have some significance. Sonia's real name is Sonali, meaning "good" which was shortened to "Sonia," to suit the American-style nickname and also a common name in Russian novels, which the father Ashoke is very fond of. Moushumi's name also has a textual significance as it means "a damp south-westerly breeze," which is often disliked by people living in the north part of America. However, Gogol feels that there is "no such thing" as a perfect name, and insists to use "only pronouns" to identify a child until the age of eighteen. Moushumi herself is not happy with her identity that is "French" continental, and intellectual" as her parents had first settled in France before migrating to America.

Both Gogol and Moushumi are childhood friends, who come from the same Bengali family background and meet each other in New York. Hence, their parents decide for their "arranged" marriage in the Bengali tradition. Suddenly the readers become aware of Moushumi having a love affair with an American banker, whom she had left because he disliked the Bengali customs and also Moushumi's family and relatives. On uniting, and getting married to Gogol, Moushumi thinks about her first love affair as a nightmare, which she should try to forget, though his memories still haunt her.

After his father's death, Gogol returns to his "orbit" and emotionally reunites with his mother and sister. This "emotional" renaissance is also echoed in Moushumi's entry in Gogol's "world." Both belong to the same "world" and also have common identities, a common homeland, and now married. Both of them "share" the same set of cultural experiences, bear the same kind of "social pressures, customs, and anxieties" that the immigrants face in a foreign land. At this stage, there are textual overturns in the story, which though may not be the demand of the plot. Moushumi is not able to forget her relationship with her first love, the wealthy American banker. This is similar to Gogol trying to move beyond his own cultural horizon when he was courting Maxine. Now, Moushumi is also wishing to move ahead to know new cultures. Such textual overturns are functional which Fairclough would call 'multi-functionality of the text. This refers to various things that occur simultaneously in the text. A text is seen as a form of action, a function or representation of people or events suitable to their identities. Texts thus have the inter-discursive function that helps in the plot of the story in a literary work.

Moushumi is however different from Gogol in the sense that she was born in India, went to France with her parents when she was a small child and came to the United States as a grown-up girl. So her courtship with Gogol is not a "return" or "family reunion" in the true sense. This is the irony that both Gogol and Moushumi always struggle to move out of their closed familial backgrounds in the United States, but it is only Gogol who can remain in the inner circle. Moushumi finally fails to sustain the familial pressures and divorces Gogol to marry Dimitri who is an acquaintance in France and who she has recently come across due to his love for French literature, a passion that Moushumi shared with him. Dimitri is a man existing outside the closed circle of Moushumi's Bengali family. He is described as a "lazy ex grad-student" with hardly any professional accomplishments. Moushumi divorced Gogol because she is unhappy with her life and marriage. She wants to escape to a world unknown to Gogol, to the world of literature, a world which Dimitri promises to offer to her. Moushumi is always allured by French literature. Lahiri seems to suggest that, unlike Gogol, Moushumi "gives in" to the pressures of cultural conformity. She fails to "sustain" her marriage with Gogol as there is too much "foreignness" in it, according to her. This reflects a logical description of the relationship between Gogol and Moushumi.

In critical discourse analysis, as Fairclough (2003) argues, this refers to acceptance or rejection of individual "standpoints" (p. 32). There is a juxtaposition represented in the relationship between Gogol and Moushumi, and Gogol's earlier relationship with two American women, Ruth and Maxine. Gogol's life with Moushumi is certainly different from what his life would have been with Ruth, or with 
Maxine. But in each of his three failed relationships, Gogol learns a lot and grows into what he wanted to become. There is also juxtaposition in what Gogol was prior to his father's death. He has learned a lot about himself, and his family values only after his father died.

\subsection{Process analysis (interpretation)}

In his second dimension of Process Analysis or Interpretation of a text, Fairclough emphasizes situational context and recommends asking a question like 'What? Who? and Why? These questions can revolve around three factors: activity, topic, and purpose (Fairclough, 1992b). Language thus becomes a vehicle of interpreting the process of producing a text. This also reflects the dialectical and rhetorical perspective of a language. For instance, The Namesake title itself puts readers into an interpreting process, forcing them to ask questions: Who does Jhumpa Lahiri refer to? Only to the protagonist or to all major characters? What is the significance of the title? The selection of this title can be justified in interpreting the textual description and asking questions like why the protagonist changed his name or what other names were available. Gogol changed his name not only to get rid of his foreign identity but to try on different identities at different stages of his life. In earlier days of his life, he uses his foreign identity and comfortably dates with two American women Ruth and Maxine, at two different times. But both relationships do not last for long. He thinks because he had a mixed and split identity. So, when he meets Moushumi, his childhood friend, he changed his name to Nikhil and therefore can marry her. A diasporic element emerges here when Gogol recalls how kids at school would tease him when teachers mispronounced his name. Though it was a unique name, Gogol was ashamed and suffered a lot. He had begun to hate his name, which had become a burden, an identity that he could not relate to. Fairclough's situational implication of a text best fits in this situation when Gogol finds himself in different situations and each time he changes his identity.

The identity crisis is faced by Gogol and Sonia, the two America born children, who undergo a rigorous process of assimilation with the American life during their school and university days. But following the death of his father, Gogol seems to have got closer to his family customs. He observes 10 days' mourning, discards all belongings of his father, shaves his head as a ritual, eats plain meals, and avoids the company of friends. At the end of ten days, his mother, Ashima, holds a gathering as a mark of respect for her departed husband in the Bengali tradition. All family friends arrive at their house, including Maxine, who is surprised to see Gogol following all mourning rituals. She asks if Gogol is still interested to return to New Hampshire to live with her and her parents, but he declines, expressing his desire to live with his mother and sister.

This seems to be a period of transition for Gogol as he returns to his own family. He rejects the Ratliff's, who was a sort of his surrogate family, who reared up his modern American self. But his father's death brings him back closer to his mother and sister. He had learned these obligations during his vacation in India, and now practicing the mourning rituals himself. Gogol is now a strict observant and faithful practitioner of family and religious rituals. He starts realizing the importance of family gatherings which his parents organized in the past. His father's death thus has a deep effect on Gogol's mind and builds a deep binding for his immediate family. This binding keeps Maxine out, a symbolic rejection of a foreign bonding. But it is also a realization that Maxine belongs to a different race, who observes different social codes and traditions. Gogol is thus an example of a second-generation immigrant youth who struggles to assimilate into the American society, and who traverse between "ingroups" and "out-groups," and finally return to the one where they find a bonding. Gogol seems to have found his real identity ultimately.

Fairclough (2001a) asserted that a society or any institution would give an identity to individuals who are a part of the society or institution. Gogol for instance finds himself in a different role, first as a 
son born in a foreign land of an immigrant father during his lifetime, and after his father's death, as a dutiful son, who despite his love and pride for having born in a foreign land, follows Indian rituals of mourning. He is not even dejected when he declined to go with Maxine to live with her parents. This situation is aligned with the sudden inclination to his Indian identity. Gogol now uses a language that witnesses his "alternating roles" (p. 148) and 'hybridity' reflected in the texts and can be described as an intermingling of two ideologies within a single text. Fairclough presents such individuals in such a situation as "likely victims" (p. 148) failing to represent any single ideology. Figure 3 depicts this interpretation in the context of the theoretical framework of this study.

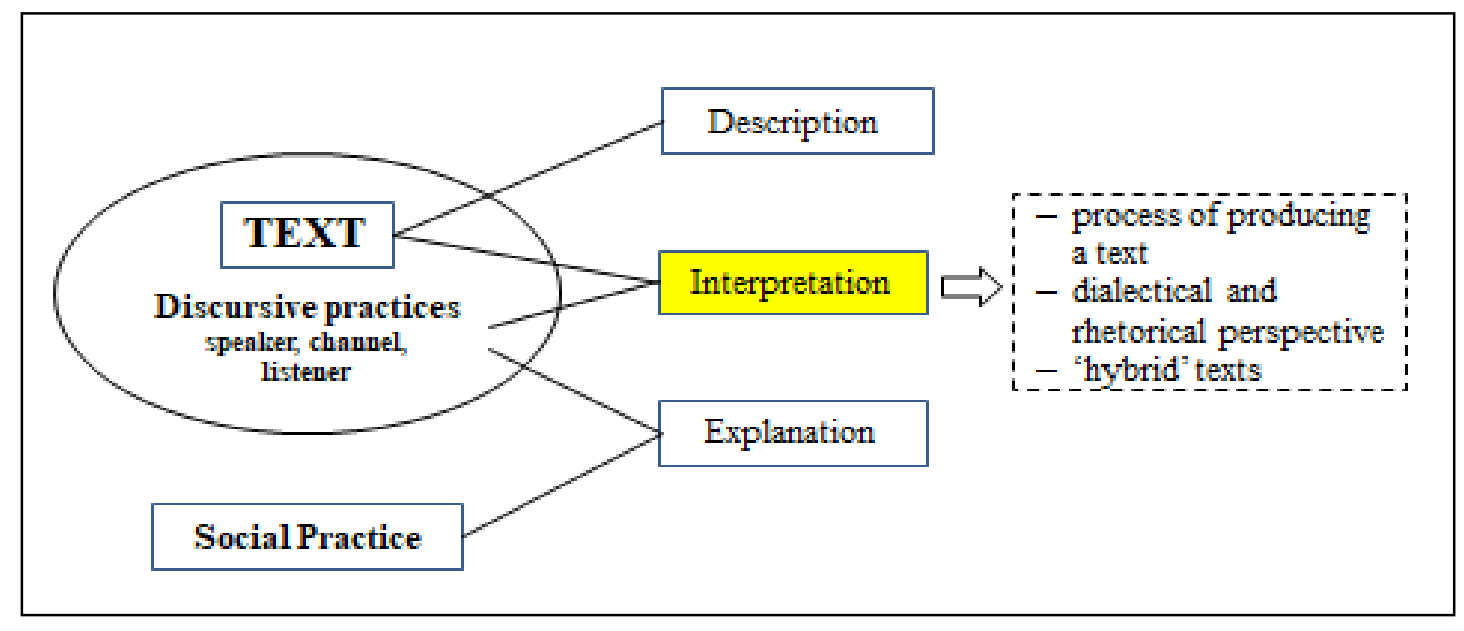

Figure 3. Fairclough's process analysis (Interpretation)

Nostalgia is inevitable in such a situation when immigrants feel "victimized" and think about their native homeland. Ashoke often reminiscences how he escaped narrowly in a train accident while reading Nikoloi Gogol's short story during a train journey. There is more of a sense of gratitude in him than the trauma of the accident. This is also the reason why he decided to call his first child, Gogol, when he was born, after the great Russian writer, for saving his life in the accident that had almost killed him. Lahiri cites this incident several times in the novel. The train accident resonates as a painful memory but also at the same time very powerful and overwhelming. It not only symbolizes the gratitude for the Russian author, but also the parental love for Gogol. Now in America, it has become a source of reminiscensing about the past.

During their sabbatical when they visited their home in Calcutta, they went to live in the same old house where they were born and had grown up. It was a very humble, simple, and suburban dwelling but the Ganguli's enjoyed every moment.

\subsection{Social analysis (explanation)}

The third dimension of Social Analysis or Explanation of a text refers to the use of a language in a social context (Fairclough, 1992a) or in "areas of social practices" (Foucault, 1989; p 25). Both Fairclough and Foucault however differentiated between discourse and language. Language is merely a manifestation of a discourse, which in turn is a form of knowledge about society and culture and also about social events.

The novel's social perspective is still larger than any of its characters. For instance, Ashima is truly a Bengali woman and wife, who likes to mix up with all her Bengali friends, and does not let them develop the feeling of being foreigners. She is often nostalgic about her native land, her home in India, and loves to speak her "native" language; but then quickly she moves from being "India-centric" to a 
more inclusive, multicultural melting pot, a truly American. She cooks Indian food on special occasions, trying to refresh her Bengali (Indian) cuisine skills, and enjoys being a center of attention in parties and celebrations hosted by the Bengali communities. She manages the house strictly with Bengali customs during festivals. The narrator tells that their marriage was an arranged marriage, unlike marriages that take place in America. Through interior monologues, the readers also come to understand the traditional element and the nativity implicit in social institutions like marriage and festivals. Their thoughts also reveal that they did not travel to America by choice, but to earn a livelihood, which is another socio-cultural fact about most diasporic families. During a sabbatical of eight months, both Ashoke and Ashima are excited to reunite with their extended families, aunts, and uncles in Calcutta. They look more confident when they speak their native tongue, and socialize with their friends and relatives. Their travel to Delhi and Agra and to visit the Taj Mahal is also symbolic of the big picture that Lahiri paints of the native place of an immigrant when he revisits his homeland.

Fairclough (1992b) considers going back into the past or involvement in social practices as things people accept and learn from the environment, culture, and society they live in. These social practices thus giving birth to discourse, not only from what is said but also how it is said and in what context. Discourses make social practices that become realities and often turn into ideologies (Fairclough, 1992b). When talking of ideology, Fairclough suggests that discourses are historical or artifacts of the past and when archived over years, they get accumulated into sets of discourses. This sets forth the relationship between discourse and social realities.

The Namesake is a perfect example of analyzing a discourse to expose the (diasporic) ideology hidden in its hybridity or the identity crisis that Gogol or Moushumi face and is well expressed in an alternating language in the text. It is a novel that represents the ideology of diaspora, which every immigrant understands and also pursues as a lifestyle. This can often be considered as the intermingling of two genres within a single text and showing how language plays a determining role to unite the two ideologies, the CDA and the diaspora. Then the question arises about the role of language in building up social practices. Fairclough calls them "articulations" to understand social events and contexts and at the same time give an extra perspective to their analysis. Figure 4 exemplifies the social analysis in the context of the framework designed for this study.

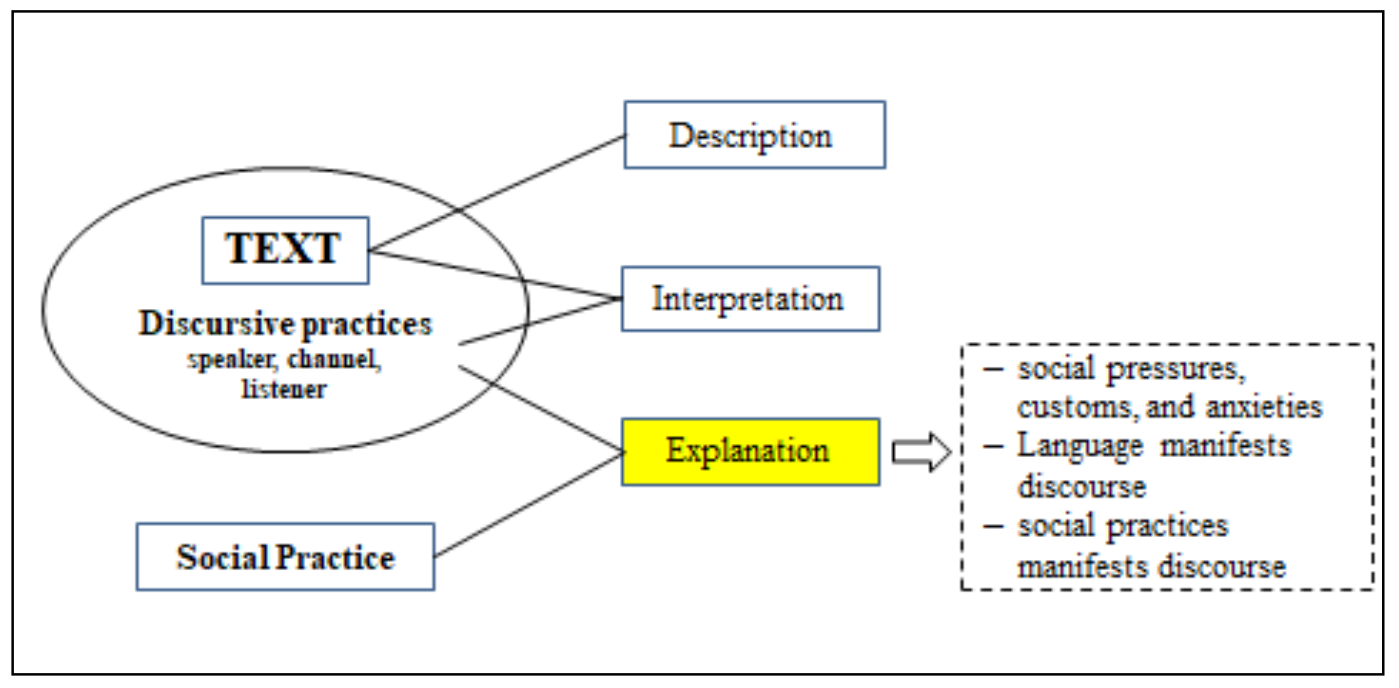

Figure 4. Fairclough's social analysis (explanation)

Lahiri's interpretation of the past as a myth or a symbol of oriental lifestyle is also portrayed when Maxine, Gogol's American girlfriend, visits their house for dinner. Ashima and Ashoke are very 
hospitable to her, though Gogol feels slightly embarrassed by the Indian food that his mother has served to Maxine. He also dislikes his father's informal appearance in front of the American guest. Later, Gogol is invited to buy Maxine's parents to the place for dinner. Lahiri presents a sharp social and cultural contrast between Gogol's parents and Maxine's. Maxine is an aborigine, urbane New Yorker, whose parents are conversant with the most current museum shows, exhibitions, and political scandals. They eat American food with rare ingredients, drink wine, and have very cultivated mannerisms related to food and eating. Interestingly, Maxine frequently calls Gogol with his new name, Nikhil, and seems to be abandoning the old one. Gogol views her parents as upper-class New Yorkers while his parents are immigrant parents. He also remembers the sabbatical he spent with his parents in India and sharply contrasts with the current vacations that he has come to spend with Maxine. The two vacations represent two different societies and lifestyles. If the Indian vacation for the Ganguli's was a familial obligation and a source of emotional gratification for reuniting with family bonds, the vacation at New Hampshire with the Ratliffs' was more as relaxation, fun, and entertainment. Both Gogol and Maxine are engaged in lounging, swimming, eating good food while Maxine's parents brooded in intellectual discussions. Gogol fails to understand this contrast, feels guilty, and wakes up in the middle of the night fearing that his mother is calling him.

Adding to this contrast, Lahiri also shows how Gogol's family is disintegrated at this point after they return from vacation. Gogol is in Maine, New Hampshire; Ashima is in Boston doing part-time work in the library; Ashoke in Ohio as a professor, his sister Sonia is in California, studying in the university. Lahiri seems to suggest that his vacation to Maine is a sort of breaking away from his family, just as the vacation to India was an attempt to reunite the family bonding. The two vacations also exposed the differences between the two families, which culminates soon into a break-up when Maxine refused to marry Gogol.

\section{Conclusion and Limitations}

This study adopted Fairclough's (1989) three-dimensional model to analyze Jhumpa Lahiri's narrative The Namesake, a diasporic novel that presents themes such as marginalization, alienation, and remembering homeland from an immigrant's point of view. The first step of description analyzed the text by focusing on characters' names, their use of language, their behavior, and anxieties about their names and identities that traversed between East and West ideologies. The reader gets aware of the shifting of language from one context to another, suggesting a 'multi-functionality of the text. The second step of interpretation emphasized the situational context and discovered that language was helped in interpreting the text. The third step of explanation required to focus on the use of language in a social context where the language was seen as a manifestation of a discourse. From a sociolinguistic perspective, a language may only identify social discourses in the text but when seen from a sociocultural perspective, the text reveals such aspects of culture and society where discourse originates from.

The study was based on the premise that such discourses that originate from social practices often turn into ideologies (Fairclough, 1992b), supported by historical artifacts accumulated into sets of discourses. Fairclough thus establishes the relationship between discourse and social realities. The Namesake proved to be a perfect example of analyzing a discourse with a socio-cultural perspective. The close reading of the text of the novel exposed the (diasporic) ideology hidden in its narrative of an immigrant family. It is a novel that represents the ideology of diaspora, from an immigrant's perspective. This study can be considered as an analysis of two genres, the CDA, and the diaspora, within a single text since it shows how language plays a determining role to unite two ideologies. 


\section{Acknowledgments}

The researchers would like to thank Prince Sattam bin Abdulaziz University (Deanship of Scientific Research) for their constant support, encouragement, and guidance.

\section{References}

Abdu, K. S., \& Khafaga, A. F. (2019). A critical discourse analysis of mind control strategies in George Orwell's nineteen eighty-four. International Journal of English Linguistics, 9(6), p421.

Ahmad, K. M., \& Ibrahim, W. H. (2018). Applying Norman Fairclough's model on JK Rowling's Harry Potter and the Sorcerer's stone: Feminism and critical discourse analysis (CDA) in children's world literature. Midad Al-Adab, 1(14), 659-680.

Alba-Juez, L. (2009). Perspectives on discourse analysis: Theory and practice. UK: Cambridge Scholars Publishing.

Amir, M. A., \& Mehmood, A. (2018). Critical Discourse Analysis of Tariq Ali's Novel "The Stone Woman": A Corpus Driven Study". International Journal of English Linguistics, 8(1), 94-106.

Awan, A. G., \& Yahya, M. (2016). Critical discourse analysis of Ahmad Ali's novel Twilight in Delhi. Science International, 28(2), 99-105.

Awan, Abdul Ghafoor \& Muhammad Yahya. (2016). Critical Discourse Analysis of Ahmad Ali's Novel "Twilight in Delhi", Science International, 28(2):2047- 2052.

Awan, Abdul Ghafoor \& Syed Ahmad Raza. (2016). The Effects of Totalitarianism and Marxism towards Dystopian society in George Orwell's selected fictions, Global Journal of Management and Social Sciences, 2(4), 21-31.

Awan, Abdul Ghafoor \& Shahida Perveen. (2015). Comparison of Sylvia Plath and Parveen Shaker with Special Reference to Their selected Poems in Feminist Perspective. Journal of Culture, Society and Development 13, 11- 19

Bezar, S. A., Azhar, M. A., \& Akhter, M. S. (2018). Fairclough's three-dimensional model: Critical discourse analysis of Blake's" Ah Sun-Flower!” New Horizons, 12(2), 59-93.

Bilal, Hafiz Ahmad. (2012). Discourse analysis of the gift of the magi. Academic Research International, 2(1), 686-694.

Brown, G., \& Yule, G. (1984). Discourse analysis. Cambridge: Cambridge University Press.

Evans-Agnew, R. A., Johnson, S., Liu, F., \& Boutain, D. M. (2016). Applying critical discourse analysis in health policy research: Case studies in regional, organizational, and global health. Policy, Politics, \& Nursing Practice, 17(3), 136-146.

Fairclough, N. (1989). Language, and power. London: Longman.

Fairclough, N. (1992a). Discourse and social change. Cambridge: Polity Press.

Fairclough, N. (1992b). Discourse and text: Linguistics and intertextual analysis within discourse analysis. Discourse and Society, 3(2), 193-217.

Fairclough, N. (1995). Critical discourse analysis: The critical study of language. London: Longman.

Fairclough, N. (1999). Linguistic and intertextual analysis within discourse analysis. In A. Jaworski $\&$ N. Coupland (eds.), The discourse reader. London: Routledge. 
Fairclough, N. (2000). Discourse, social theory, and social research: The discourse of welfare reform. Journal of Sociolinguistics, 4(2), 163-95.

Fairclough, N. (2001a). Critical Discourse Analysis as a method in social scientific research. In R. Wodak \& M. Meyer (eds.), Methods of critical discourse analysis. London: Sage Publications.

Fairclough, N. (2001b). Language and power (2nd ed.). London: Longman.

Fairclough, N. (2003). Analyzing discourse: Textual analysis for social research. London: Routledge.

Foucault, M. (1989). Archaeology of knowledge. London and New York: Routledge Classics.

Gee. P. J. (2010). An introduction to discourse analysis: Theory and method (3rd ed.). UK: Taylor \& Francis e-library.

Hatch, E and Lazaraton, A. (1991). The research manual: Design and statistics for applied linguistics. Massachusetts, MA: Heinle \& Heinle Publishers

Heller, M. (2001). Discourse and Interaction. In D. Schiffrin, D. Tannen, \& H. E. Hamilton (Eds.), The handbook of discourse analysis (pp. 250-264). Oxford: Blackwell.

Hosseini, A., \& Sattari, E. (2018). A review of Naguib Mahfouz's The Beggar based on Norman Fairclough's critical discourse analysis. PEOPLE: International Journal of Social Sciences, 4(1).

Hua, Chen. (2013). Critical discourse analysis of women language at the lexical level in Sense and Sensibility. Academic Research International, 4(2), 347-361

Ilyas, Mohammed. (2020). Language with socio-cultural perspective in Ralph Ellison's Invisible Man: A critical discourse analysis approach. Talent Development \& Excellence, 12(1), 1264-1276

Istari, Y. (2018). The impact of hybridity and mimicry on the Indian immigrants' identity: A postcolonial analysis in Jhumpa Lahiri's The Lowland (Doctoral Dissertation, Yogyakarta State University).

Janks, H. (1997). Critical discourse analysis as a research tool. Discourse: Studies in the Cultural Politics of Education, 18(3), 329-342.

Khan, R. N., \& Qureshi, A. W. (2018). The politics of voice in the stereotypical representation of the Pashtuns: A critical study of Khaled Hosseini's novels. Global Social Sciences Review, 3(2), 387403.

Kiren, A., \& Awan, A. G. (2017). Critical Discourse Analysis of Jane Austien's Novel Pride and Prejudices. Global Journal of Management, Social Sciences, and Humanity, 3(3), 482-498.

Lahiri, J. (2004). The Namesake. London: Fourth Estate.

Mahmood, S. I. \& Majeed, M. R. (2019). Critical discourse analysis of figurative language in the selected poems by Langston Hughes. Retrieved from http://conferences.koyauniversity.org/ index.php/enlc/ EnLC2019/paper/ view/ 170/56

O’Neill, P. (1996). Fictions of Discourse: Reading narrative theory. Canada: University of Toronto Press.

Paziraie, Mandan Eftekhar. (2012). A discourse of the novel "Things Fall Apart" and two of its Persian translations at micro and macro levels, English Linguistics Research, 1(2).

Sabir, M., \& Kanwal, N. (2018). Norman Fairclough's model as a research tool in the critical discourse analysis of Robert Frost's poem Fire and Ice. Faculty of Social Sciences and Humanities University of Wah, Wah Cantt, 83. 
Sameen, S., Farid, A., \& Hussain, M.S. (2021). A critical discourse analysis of the impact of codeswitching on modern adult language learners' motivation in Pakistan. Journal of Language and Linguistic Studies, 17(Special Issue 1), 109-121.

Schiffrin, D., Tannen, D., \& Hamilton, H. E. (Eds.). (2001). The Handbook of Discourse Analysis. UK: Blackwell Publishers.

Stubbs, M. (1997). Whorf's children: Critical comments on critical discourse analysis (CDA). British studies in applied linguistics, 12, 100-116.

van Dijk, T.A. (1998a). Towards a theory of context and experience models in discourse processing. Hillsdale, NJ: Erlbaum.

Van Dijk, T. A. (1990). Discourse \& Society: a new journal for a new research focus. Discourse \& Society, 1(1), 5-16.

Van Dijk, T. A. (1997). Discourse as interaction in society. In T. A. van Dijk (Ed.), Discourse as social interaction (pp. 1-37) London: Sage.

Van Dijk, T.A. (1983). Discourse analysis: its development and application to the structure of news, Journal of Communication. 33(2) pp. 20-43

Van Dijk, T.A. (1998b). Critical discourse analysis. Hillsdale, NJ:

Van Leeuwen, T. (1996). The representation of social actors, in C.R. Caldas Coulthard and M. Coulthard (eds), Texts and Practices: Readings in critical discourse analysis. London: Routledge, pp. 32-70.

Wodak, R., \& Meyer, M. (2009). Critical Discourse Analysis: history, agenda, theory, and methodology. Methods of critical discourse analysis (pp. 1-33). London: SAGE

Ziad, K., \& Ouahmiche, G. (2019). Gender positioning in the visual discourse of Algerian secondary education EFL textbooks: Critical image analysis vs teachers' perceptions. Journal of Language and Linguistic Studies, 15(3), 773-793. Doi: 10.17263/j1ls.631510

\section{AUTHORS BIODATA}

Dr. Mohmmed Ilyas is a senior professional, with interdisciplinary expertise in language and literature teaching. With more than three decades of a proven track record of strong, decisive, academic expertise, Dr. Ilyas has assimilated a unique blend of teaching, research, and curriculum planning. His areas of expertise include expatriate writings, CDA, and $20^{\text {th }}$-century fiction. He is endowed with a strong focus on academics and makes a tactical execution of his teaching methodology, which makes an immediate impact and long-term value to both faculty and students. He has widely published his research in renowned Scopus and peer-reviewed journals and attended several conferences.

Dr. Naeem Afzal is affiliated with the Department of English, College of Sciences and Humanities, Prince Sattam bin Abdulaziz University, Saudi Arabia. He has researched and published papers on topics related to media discourse, discourse analysis, rhetoric, and critical discourse analysis. 